\title{
Límites y paradojas de una fotografía de prensa: análisis de una foto de Madres de Plaza de Mayo durante la dictadura militar en Argentina
}

\section{Limits and paradoxes of a press photograph: analysis of a photo of Mothers of Plaza de Mayo during the military dictatorship in Argentina}

\author{
Cora Gamarnik \\ Facultad de Ciencias Sociales /UBA-UNM, Argentina \\ coragamarnik@gmail.com \\ https://orcid.org/0000-0002-0128-5453
}

\section{Resumen:}

Este artículo aborda la historia de una fotografía que se utilizó como símbolo de una posible reconciliación entre las Madres de Plaza de Mayo y la dictadura militar en Argentina. El 5 de octubre de 1982, ocho organismos de derechos humanos convocaron en forma conjunta a una movilización en reclamo por la aparición con vida de los detenidos-desaparecidos. Ese día se produjo una fotografía que aparentaba mostrar un abrazo entre un policía y una madre. La fotografía tuvo inmediata trascendencia mediática y se utilizó para sostener una supuesta política de reconciliación entre las organizaciones de derechos humanos y las fuerzas represivas que, en los hechos, jamás existió. Sus usos e interpretaciones permiten analizar tanto las limitaciones como las posibilidades de la fotografía periodística a la hora de constituirse como prueba y, al mismo tiempo, como símbolo de un acontecimiento. El carácter polémico y el éxito en términos periodísticos y fotográficos ubican esta imagen como un objeto de estudio privilegiado para analizar la relación entre dictadura, medios y fotografía, así como para reflexionar sobre la capacidad de una imagen para disputar el sentido histórico de un hecho y de influir en la opinión pública.

\begin{abstract}
:
This article addresses the story of a photograph that was used as a symbol of a possible reconciliation between the Mothers of the Plaza de Mayo and the military dictatorship in Argentina. On October 5, 1982, eight human rights organizations jointly called for a mobilization to demand the return, alive, of the detained and disappeared. That day a photograph was produced that appeared to show a hug between a policeman and a mother. The photograph had immediate media significance and was used to support a supposed policy of reconciliation between human rights organizations and the repressive forces, which in reality never existed. In turn image's uses and interpretations allow us to analyze both the limitations and the possibilities of press photography when constituting itself as evidence and at the same time as a symbol of an event. The controversial nature and the success in journalistic and photographic terms places this image as a privileged object of study to analyze the relationship between dictatorship, media and photography as well as to reflect on the capacity of an image to dispute the historical meaning of a fact and to influence the public opinion.
\end{abstract}

Palabras clave:Dictadura militar en Argentina (1976-1983); periodismo gráfico; fotografía; Madres de Plaza de Mayo; fotografía periodística; política.

Keywords: Military dictatorship (1976-1983) in Argentina; Graphic journalism; Photography; Mothers of Plaza de Mayo; Journalistic photography; Politics. 


\section{La construcción de la imagen de las Madres de Plaza de Mayo}

Este artículo aborda la historia de una fotografía que se utilizó como símbolo de una posible reconciliación entre las Madres de Plaza de Mayo y la dictadura militar en Argentina. Para hacerlo, reconstruimos el contexto de su publicación, relevamos la voz de los fotógrafos y otros actores sociales y políticos involucrados, cruzamos fuentes orales con fuentes visuales, analizamos las publicaciones periódicas de los días anteriores y posteriores a la toma de la imagen. Realizamos de esta forma lo que llamamos una "arqueología de la imagen”.

La dictadura cívico-militar instaurada en Argentina el 24 de marzo de 1976 implementó un régimen represivo cuyas dimensiones y modalidades (secuestros, desapariciones, torturas y asesinatos masivos) no tuvo precedentes en la historia nacional. Producto de ello surgió, entre otros organismos, un movimiento llamado Madres de Plaza de Mayo, que tuvo como objetivo central buscar a sus hijos e hijas que habían sido secuestrados y estaban desaparecidos. La fotografía de prensa fue un pilar fundamental para la construcción de su imagen.

Las Madres (y luego las Abuelas de Plaza de Mayo) se transformaron no solo en un colectivo de lucha y resistencia, sino también en un símbolo contra la dictadura. Ese símbolo fue construido en parte a través de la producción y circulación de cientos de fotografías que ayudaron a crear esa imagen, que, a su vez, repercutía en su propia identidad como movimiento social, en la propia mirada que las madres comenzaron a tener sobre sí mismas. ${ }^{1}$

La mayoría de ellas no tenían formación ni militancia previa a las desapariciones. Una cierta subestimación por parte de la dictadura y una percepción tardía de la relevancia que podían adquirir permitieron que emergiera lo que sería uno de los principales focos de resistencia frente al poder militar. También ellas tardaron en concebirse a sí mismas como un movimiento político. La inorganicidad inicial se ve reflejada en su propio nombre ligado a su lugar de encuentro. Tampoco eran un grupo numéricamente importante al principio. ${ }^{2}$

Con la desesperación por no saber dónde estaban ni qué les habían hecho a sus hijos e hijas, sin saber muy bien qué hacer ni dónde ir, se fueron encontrando

\footnotetext{
1. Para un estudio acerca de cómo se fue construyendo de la imagen de las Madres de la Plaza de Mayo, ver Gamarnik (2010).

2. Para la reconstrucción de la historia de las Madres de Plaza de Mayo, ver Gorini (2006).
} 
unas a otras en sus dolorosos peregrinajes. La frustración tras las gestiones que realizaban y el profundo desconocimiento de lo que verdaderamente sucedía en los centros clandestinos de detención y del destino final de la mayoría de sus hijos e hijas hizo que tomaran decisiones que otros tildaban de temerarias e imprudentes mientras para ellas eran de sentido común: interpelar directamente a la gobernante Junta Militar frente a la Casa de Gobierno, con consignas viscerales: "Los desaparecidos, que digan dónde están”, "Aparición con vida", "Con vida los llevaron, con vida los queremos".

En esos primeros años, diversos fotógrafos y periodistas ayudaron a que este pequeño grupo de madres adquiriera una trascendencia internacional. Pierre Bousquet, subdirector de France Press entre 1975 y 1980 en Argentina y único corresponsal extranjero acreditado ante las Fuerzas Armadas, señala: "Para hacer un frente común, hicimos entre los corresponsales de las agencias $A P$, Reuter, EFE, ANSA, Prensa Latina y Tass un acuerdo no escrito de intercambiar datos" (Bousquet, 1983). La agencia francesa estaba al tanto de la situación de los derechos humanos en el país y le dio a su corresponsal en Argentina libertad para seguir el tema. Mientras que para los periodistas argentinos involucrarse era un riesgo físico concreto, para los corresponsales extranjeros se hacía más sencillo debido a que la Junta Militar quería evitar enfrentamientos con la prensa internacional.

Bousquet y otros periodistas establecieron una verdadera "malla de protección" alrededor de las Madres: asistían a la Plaza para que no se quedaran solas frente a la policía, difundían sus reclamos por el mundo y hasta marchaban de su brazo para evitar que las reprimieran. Varios fotógrafos fueron detenidos en ocasión de manifestaciones que las Madres organizaban (Gorini, 2006, p. 87; Bousquet, 1983, p. 59).

La desaparición forzada de personas fue la principal modalidad represiva durante la dictadura militar. La propia figura del "desaparecido" implicaba su ocultamiento, y el de su destino, de la vista social. Pero los secuestros combinaban una cierta visibilidad (de los allanamientos, de los operativos y en algunos casos de la aparición de cadáveres) con el secreto de lo que sucedía con los detenidos en los centros clandestinos de detención. Esto fue, como señala Pilar Calveiro (1988), una política específica de diseminación del terror. Al mismo tiempo, el 
terrorismo de Estado para su aplicación había implementado una política de desinformación, censura y manipulación mediática a fin de ocultar sus crímenes, mientras simultáneamente generaron una política en imágenes que mostraba la "normalidad" del funcionamiento social y el "rostro humano" de los máximos responsables del régimen.

A medida que las Madres -y luego también las Abuelas- adquirían mayor repercusión nacional e internacional, la dictadura desarrolló diversas acciones para neutralizarlas. En una primera instancia la estrategia frente a las preguntas de los corresponsales extranjeros por la actividad de las Madres y por el destino de sus hijos fue acusarlas de "subversivas al servicio del terrorismo internacional para dañar la imagen del país en el exterior” y tratarlas de locas. Pierre Bousquet cuenta cómo surgió esa denominación:

Jean Pierre Bousquet: Como venían regularmente tenía conocidas que habían venido a denunciar secuestros (...) Por eso cuando me llamaron (...) para la primera manifestación fui. (...) primero hacían filas para denunciar en comisarías (...). Y después de hacer la fila se fueron a Plaza de Mayo, un grupito minúsculo, pero un primer paso.

Entrevistadoras: Desde el primer día, desde el 30 de abril, ¿estuvo con las 14 madres entonces?

JPB: Sí y hasta que me fui. Cada jueves [iba] para ver qué pasaba. Porque no sabía si podían intervenir policías a secuestrar a algunas (...). La casualidad daba que después iba al Estado Mayor del Ejército, muy cerca de Plaza de Mayo (...) porque el briefing semanal se daba el jueves. (...)

Entrevistadoras: Entonces toda la idea de que las llamaban locas sale de ese briefing semanal (...) ¿A quién escuchó usted que le decían locas?

JPB: Bueno varios, pero uno de los principales era el jefe de prensa. Cuando le preguntaba: “¿Qué son esas mujeres?”, decía “que son unas locas de mierda”, con toda la connotación que tiene en la Argentina. Y se lo relaté después a las mujeres. “¿Saben qué dicen ellos de ustedes? Que ustedes son unas locas”, y (...) creo que Marta Antokoletz me dijo "bueno, sí, somos locas". ${ }^{3}$

3. Entrevista inédita realizada a Jean Pierre Bousquet, en Narbonne (Francia), el 21 de noviembre de 2010, por Nadia Tahir y Claudia Feld. 
Frente a ese discurso su propia presencia imponía otra verdad. Sus rostros, su tristeza, su solidaridad, su resistencia, sus actividades de búsqueda, su imagen, en definitiva, eran el reverso del estereotipo de "locas y subversivas" con la que la dictadura trató de identificarlas. Su angustia, sus rondas y marchas, sus formas de reclamo eran una denuncia constante que posibilitó ir permeando el silencio, la incredulidad y el desconocimiento impuesto por el terror. La ronda alrededor de la pirámide y el pañuelo blanco surgieron de la necesidad, pero se fueron transformando en símbolos reconocibles. En el imaginario social y cultural dominante, toda madre tiene el deber de cuidar y bregar por la seguridad de sus hijos y eso era precisamente lo que hacían ellas. ¿Cómo cuestionar a esas madres que cumplían con su deber que, por otro lado, coincidía con el ideal dominante de familia que la dictadura proclamaba?4

Una característica especial de su imagen era justamente su rol de madres. Mujeres sencillas, amas de casa que andaban con carteras o bolsas de hacer las compras, que caminaban alrededor de la plaza con sandalias o zapatos de taco bajo, mujeres que enfrentaban la represión, que caminaban juntas tomadas de los brazos mientras eran rodeadas de policías. Mujeres llorando y consolándose. Mujeres resistiendo. La imagen de las Madres que la mirada y el trabajo profesional de los fotógrafos permitió hacer circular favorecía la empatía con ellas, generaba compasión, llamaba a la solidaridad y provocaba indignación hacia el régimen.

A medida que su presencia en la Plaza de Mayo y en otras ciudades del interior del país fue cada vez más efectiva y visible, comenzaron a sufrir la represión en carne propia: les impedían permanecer paradas o marchar, las llevaban detenidas, las golpeaban, las reprimían. Tres de ellas, entre otras su primera presidenta, fueron secuestradas, torturadas y asesinadas. 5

\footnotetext{
4. Para profundizar en este tema, ver Filc (1997).

5. Entre el 8 y el 10 de diciembre de 1977, doce integrantes de un grupo más amplio de personas que se reunían en la Iglesia de la Santa Cruz (Ciudad de Buenos Aires) para organizar la búsqueda de los desaparecidos fueron secuestrados y asesinados por la Marina. Entre ellos, se encontraban las Madres de Plaza de Mayo Azucena Villaflor de De Vincenti, su primera presidenta, y otras dos integrantes del movimiento, Esther Ballestrino de Careaga y María Eugenia Ponce de Bianco. Estaban también las monjas francesas Alice Domon y Léonie Duquet y otros familiares de desaparecidos. En el año 2005, el Equipo Argentino de Antropología Forense (EAAF) logró identificar los restos de las tres fundadoras de las Madres que habían sido enterradas como NN después de haber sido encontradas en las costas de San Bernardo y Santa Teresita entre diciembre de 1977 y enero de 1978. Se demostró también que habían sido arrojadas al mar desde los aviones
} 
En la prensa argentina afín al régimen, por su parte, lo que había era directamente ausencia de noticias o su presentación confusa, tergiversada y/o descontextualizada. Las Madres comprendieron muy pronto que, para que su reclamo sea escuchado y trascendiera las fronteras nacionales, necesitaban tener una estrategia frente a los medios de comunicación. Se habían dado cuenta, desde sus primeras reuniones, de que la presencia de periodistas y fotógrafos nacionales y extranjeros las protegía, pero no solo eso, también les daba la visibilidad que la dictadura y los medios nacionales les negaban. Resolvieron entonces que, cuando llegara algún personaje internacional importante al país, se harían presentes en los actos públicos. Cada ocasión que les permitiese llamar la atención de los medios no debía ser desaprovechada. Como señala Gorini (2006, p. 17), ser vistas se transformó en una obsesión para ellas.

Mientras la dictadura negaba la existencia de los desaparecidos, su presencia pública y mediática lo desmentía. Al doble ocultamiento, de los desaparecidos y de sus familiares buscándolos, se les opuso una doble visibilidad. Por un lado, las Madres y otros familiares comenzaron a portar las fotos de sus hijos e hijas, esposos, mujeres, nietos y nietas, devolviéndoles un rostro, una identidad, una historia y un lazo social, volviendo visibles a quienes habían sido arrancados de sus vidas. Por otro lado, ellas mismas estaban invisibilizadas. Ahí es donde la acción de algunos periodistas y fotorreporteros permitió ayudar a quebrar esta segunda invisibilización. ${ }^{6}$ Varios fotógrafos de prensa señalan que durante esos años documentaban las acciones de las Madres y de otros familiares, fotografiándolos contraviniendo las directivas de las empresas de medios para las que trabajaban y, en algunos casos, bajo riesgo físico, sabiendo que ningún medio por entonces publicaría esas imágenes. ${ }^{7}$

de las Fuerzas Armadas en los llamados "vuelos de la muerte".

6. Nos referimos a fotorreporteros en masculino porque en Argentina las mujeres se pudieron ir incorporando muy lentamente al ejercicio profesional del fotoperiodismo. En los años ochenta hay algunas incorporaciones, pero de forma excepcional, y van ingresando más sistemáticamente a partir de los años noventa y dos mil.

7. Estos datos surgen de entrevistas realizadas por la autora, entre otros, a Daniel García (fotógrafo por entonces de NA), Pablo Lasansky (por entonces, trabajaba en NA), Eduardo Longoni (por entonces, trabajaba en NA), Aldo Amura (por entonces, free lance), Daniel Merle (por entonces, reportero de SIGLA), Bécquer Casaballe (por entonces, fotógrafo de Clarín), Carlos Pesce (por entonces, fotógrafo de 7 Días Ilustrados), Mario Manusia (editorial Atlántida) y Enrique Rosito (Agencia DYN). 
La imagen por excelencia que se pudo ver de las Madres en las fotografías más difundidas desde finales de la dictadura hasta hoy son fotografías que muestran su tristeza y dolor unidos a gestos de solidaridad y afecto, imágenes que simbolizan la idea de la voluntad y la perseverancia, que muestran su fragilidad pero, al mismo tiempo, su entereza e imágenes en las que se las puede ver resistiendo a la represión ${ }^{8}$. Nora Cortiñas,9 Madre de Plaza de Mayo-Línea Fundadora, destaca en consonancia:

Las fotos sirvieron para identificarnos como grupo, siempre buscábamos que hubiera fotógrafos en nuestras actividades y llamábamos a los diarios para avisar de las cosas que íbamos a hacer (...). El rol de los fotógrafos ayudó totalmente para la denuncia cuando no se podía poner en letras lo que el hecho representaba. Las [imágenes] de la represión en las calles, los milicos con los fusiles provocándonos, todo eso ayudó para que en el mundo entero se conociera el drama que se vivía. Nosotras siempre le estuvimos agradecidas a la prensa gráfica. Cada año ellos en sus muestras iban poniendo como evolucionaba el tema de derechos humanos. ${ }^{10}$

Las manifestaciones especialmente vinculadas a los derechos humanos comenzaron a hacerse más públicas y visibles hacia 1981. Los fotógrafos las documentaban y en una especie de espiral ascendente, a medida que aumentaba la producción de imágenes de estos hechos, comenzó a registrarse un aumento de la represión policial hacia los reporteros gráficos. La dictadura percibió rápidamente el impacto que tenían las fotografías de la represión en el espacio público y las imágenes emotivas de las Madres de Plaza de Mayo que ellos producían. Cuando, en 1982, empiezan a sucederse distintas manifestaciones en contra de la dictadura, la persecución a los reporteros gráficos, las palizas, el robo de rollos y la rotura de sus cámaras pasan a ser parte de la rutina de su trabajo cotidiano. La dictadura había confiado hasta entonces en la censura y

\footnotetext{
8. Para un análisis más en profundidad de estas fotos, ver Gamarnik (2010). En esa oportunidad, el corpus de fotografías que analizamos estuvo compuesto por las imágenes más utilizadas cuando se habla del golpe militar del 24 de marzo de 1976 y de la dictadura en general en libros, películas, vídeos, páginas $w e b$, folletos, suplementos especiales de diarios y revistas, documentales, reproducciones en la prensa internacional, muestras de fotos, exposiciones, conmemoraciones, actividades relacionadas con los derechos humanos, búsquedas en Google, actividades escolares y acciones de los propios reporteros gráficos, entre otras.

9. Nora Cortiñas es la madre de Carlos Gustavo Cortiñas, detenido-desaparecido el 15 de abril de 1977, cuando tenía 24 años. Nora participó de las reuniones del primer grupo de Madres de Plaza de Mayo desde los comienzos de la organización y hoy, con noventa años, es una de los principales referentes de Madres-Línea Fundadora. Es también una de las personas más admiradas, queridas y respetadas del movimiento de derechos humanos en Argentina.

10. N. Cortiñas, comunicación personal, 30/6/2009.
} 
autocensura de los propios medios, pero esto ahora resultaba insuficiente. Comenzaron entonces a impedir la producción misma de las imágenes.

La forma en que las Madres eran fotografiadas fue un instrumento de visibilidad social que permitió la expansión e identificación de una franja más amplia de la población con sus reclamos. Esas fotos viajaban y llegaban a grupos de exiliados que las usaban en sus acciones de denuncia internacional. ${ }^{11}$ Estas imágenes se convirtieron en un poderoso soporte comunicacional que contribuyó a difundir su búsqueda y sus reclamos. Al mismo tiempo, las fotos de las Madres y otros familiares portando imágenes de sus seres queridos permitieron romper la doble ocultación: las desapariciones mismas y la búsqueda de los desaparecidos.

\section{La foto del falso abrazo}

Hacia 1982, a la crisis provocada por la derrota bélica en las Islas Malvinas se sumó una crítica situación económica y social en el país. Las FF.AA. comenzaron a preparar su retirada del poder, pero montaron un andamiaje jurídico que les permitiese no rendir cuentas por las violaciones de los derechos humanos que habían cometido. Frente a esto, las Madres de Plaza de Mayo, junto con otros organismos de derechos humanos, convocaron en forma conjunta a una movilización el 5 de octubre de 1982, llamada "Marcha por la vida y la defensa integral de los derechos humanos”.

La Junta Militar prohibió la manifestación y montó un operativo represivo de grandes dimensiones que incluyó a 800 efectivos y a la división de policía montada portando sables. ${ }^{12}$ La marcha a la que concurrieron aproximadamente 10.000 personas fue la más numerosa de las registradas en relación con el reclamo por los desaparecidos desde la instalación de la dictadura militar. Los fotógrafos, como venían realizando hasta entonces, la cubrieron y produjeron fotos emblemáticas de la resistencia de las Madres que encabezaban la columna de manifestantes sobre todo cuando la policía las enfrentó con caballos. Una de

\footnotetext{
11. Enrique Rosito (fotógrafo de la agencia DYN en aquel entonces) mandó rollos sin revelar al aeropuerto de Ezeiza y vía algún pasajero lo enviaba para que llegase a Francia o a España y sea entregado a alguien que lo esperaba a su llegada (E. Rosito, comunicación personal, 2011).

12. Un trabajo previo sobre esta manifestación, sobre su repercusión en la prensa y sobre la historia de la foto que llamamos del "falso abrazo" puede leerse en Gamarnik (2020). Este texto es una ampliación y continuación de dicho artículo.
} 
estas fotos, tomada por Eduardo Longoni, es uno de los iconos de las imágenes de resistencia de las Madres de Plaza de Mayo hasta hoy.13

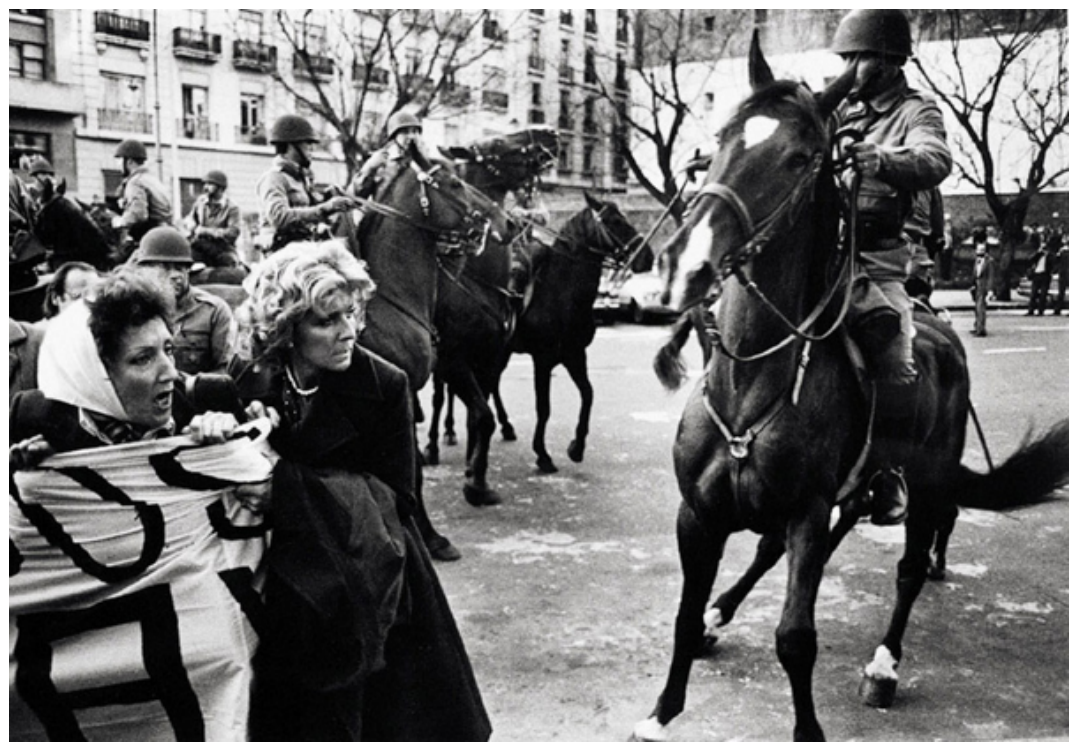

F1. Marcha por la Vida, 5 de octubre de 1982. Fotografía de Eduardo Longoni.

Cuando la manifestación llegó a la intersección de Paseo Colón y Belgrano (a cinco calles de la Plaza de Mayo, en pleno centro neurálgico de la Ciudad de Buenos Aires), un cordón policial le impidió el paso. El entonces subcomisario Carlos Gallone estaba al frente y era quien debía impedir que la columna avanzara. En el lugar en donde el frente de la manifestación se topó con el cordón policial comenzó a vivirse mucha tensión. Nora Cortiñas fue la encargada de dialogar con Gallone para solicitarle que las dejasen continuar la marcha. La escena estaba rodeada de personas que acompañaban a las Madres, periodistas y fotógrafos. Marcelo Ranea, enviado de la agencia DYN, era uno de ellos. Tenía una máquina Nikon FM que podía fotografiar cuatro cuadros por segundo y realizó durante la situación una secuencia de nueve fotos. En las seis primeras se ve cómo Nora Cortiñas interpela a Gallone, gesticula, reclama, no lo toca, está nerviosa y enojada. Se percibe la tensión en su rostro, se ve que grita, se ven manos que la agarran para sostenerla. Gallone, por su parte, está rígido frente al reclamo como explicando algo.

13. Eduardo Longoni es un fotógrafo de larga trayectoria en Argentina; en el momento de la manifestación trabajaba para la agencia Noticias Argentinas. 

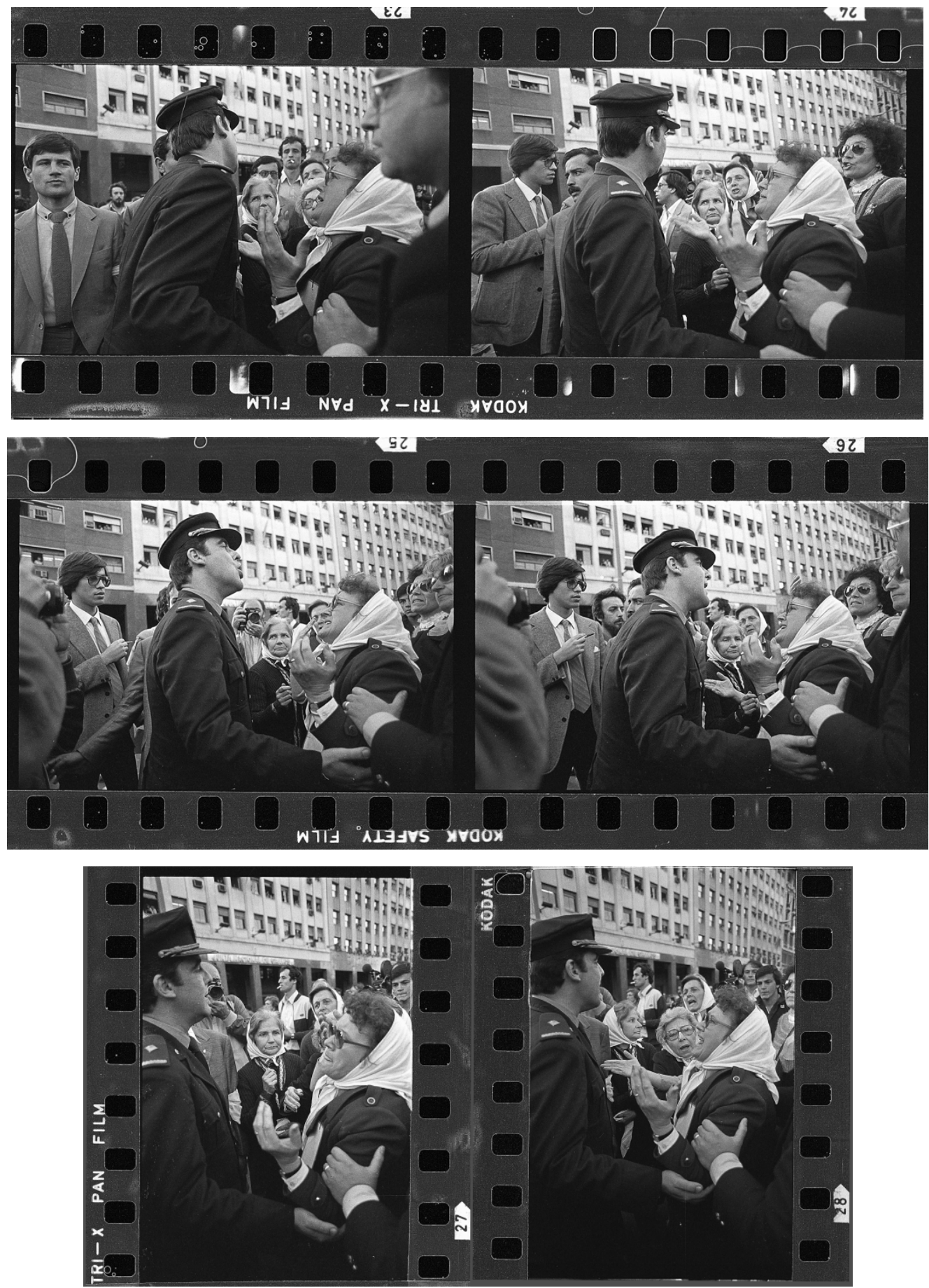

F2. Marcha por la Vida, 5 de octubre de 1982. Secuencia de fotos tomada por Marcelo Ranea /DYN. Fotogramas 23, 24, 25, 26, 27 y 28.

En el fotograma 29 -la séptima foto de la secuencia de Ranea-, se ve que había transcurrido un lapso de tiempo desde la escena anterior y otra madre, Susana de Leguía, queda en el centro de la escena. ${ }^{14}$ En ese fotograma, se ve un aparente

14. Susana de Leguía, ya fallecida, era la madre de Enrique Leguía Benítez, desaparecido el 19 de agosto de 1977 mientras estaba realizando el servicio militar. Su caso es el número 2281 de la 
abrazo entre Gallone y dicha madre. Nora Cortiñas está ahora en un costado y sigue gritando con su mirada dirigida a Gallone.

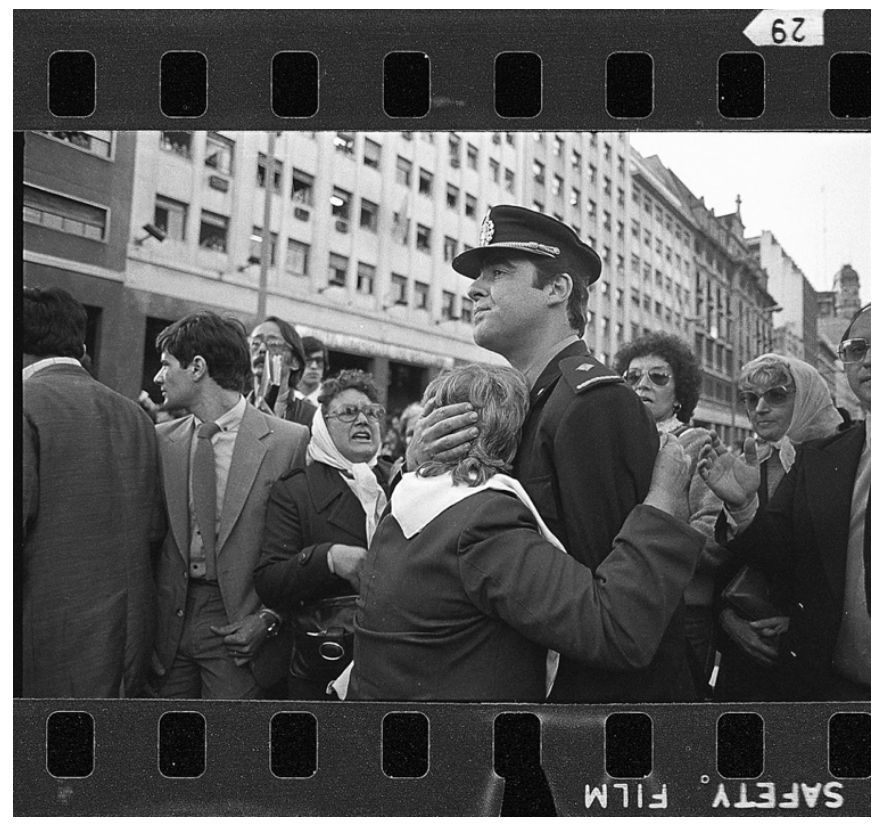

F3. Marcha por la Vida, 5 de octubre de 1982. Fotogramas 29. Marcelo Ranea / Agencia DYN.

En las dos fotos siguientes (fotogramas 30 y 31), vuelve a observarse la tirante situación: se puede ver cómo Susana de Leguía está llorando, angustiada, y Gallone la mira rígido, tenso. Una mujer trata de agarrar o sostener a Susana de Leguía y otra trata de contener el brazo de Gallone. En el fotograma 31, la madre, llorando, comienza a alejarse.

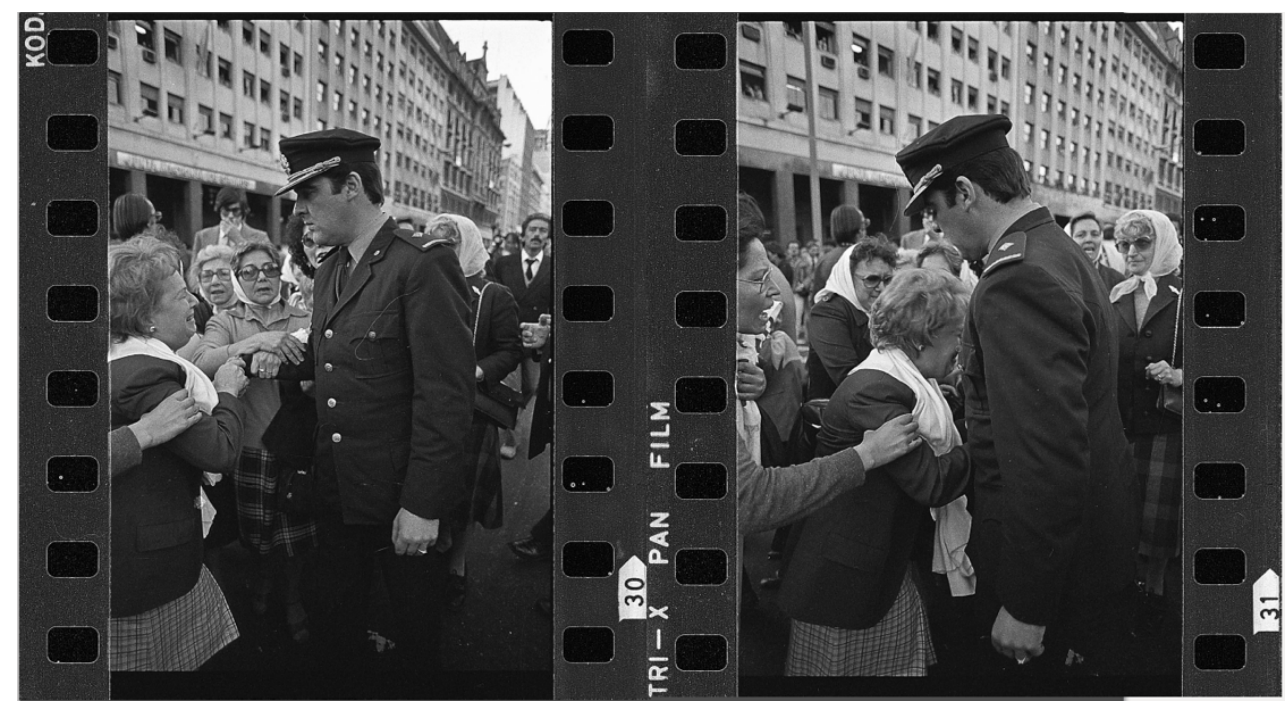

F4. Marcha por la Vida, 5 de octubre de 1982. Fotogramas 30-31. Marcelo Ranea / Agencia DYN.

Conadep (Comisión Nacional sobre la Desaparición de Personas). 
Según pudimos reconstruir sobre la base de diversos testimonios de testigos de ese momento, Susana de Leguía, una madre no habituada a concurrir a las manifestaciones, entra en una crisis de nervios al enterarse de que no las dejaban continuar e increpa llorando a Gallone, intentando golpearlo en el pecho. ${ }^{15} \mathrm{El}$ policía, sabiendo que estaba rodeado de fotógrafos, periodistas y otras madres, la agarró con sus dos brazos para frenarla y la apretó contra sí mismo. Todos los testimonios coinciden en que fue una escena violenta y que no hubo un abrazo ni intencionalidad afectiva alguna. Eso también puede verse cuando se analiza la secuencia completa de Ranea y cuando se observa otra foto tomada en el mismo momento por otro fotógrafo que analizaremos más adelante. Sin embargo los usos periodísticos posteriores del fotograma 29 hicieron hincapié no solo en el abrazo -como si hubiera habido una intencionalidad por ambas partes de realizarlo-, sino en el símbolo que ese abrazo significaba: la posibilidad de la reconciliación entre las madres de detenidos-desaparecidos y los represores.

\section{Arqueología de una imagen}

La agencia DYN envió el fotograma 29 como “imagen-síntesis” del acontecimiento por radiofoto al interior y a los medios internacionales e incluyó copias grandes en papel para los diarios de tirada nacional. La fotografía fue portada de los diarios Clarín, La Voz y Crónica en Argentina y del diario El País de España. El diario La Nación le dedicó un recuadro especial y la revista Siete Días la publicó a doble página. También salió publicada en el New York Times, el Miami Herald (EE.UU.) y el Excelsior (México), entre otros. Durante los días siguientes, diarios y revistas de tirada nacional y local la publicaron y/o hicieron mención a la misma. El diario Clarín, dueño de un porcentaje accionario de la agencia DYN, fue el que más relevancia le otorgó. ${ }^{16}$ El 6 de octubre de 1982, al día siguiente de la manifestación, la publicó en su portada a gran tamaño con el título "Pacífica concentración en el centro".

\footnotetext{
15. Se pueden leer los testimonios de Nora Cortiñas, Alejandro Amdan, Jorge Sánchez y del propio Marcelo Ranea reconstruyendo los acontecimientos y lo vivido en ese momento en Gamarnik (2020).

16. Clarín era el diario de mayor circulación en Argentina desde mediados de los años setenta, con una amplia influencia en la opinión pública. Desde el año 1977, se convirtió en socio comercial de la dictadura militar a través de la empresa Papel Prensa, junto con los diarios La Razón y La Nación.
} 


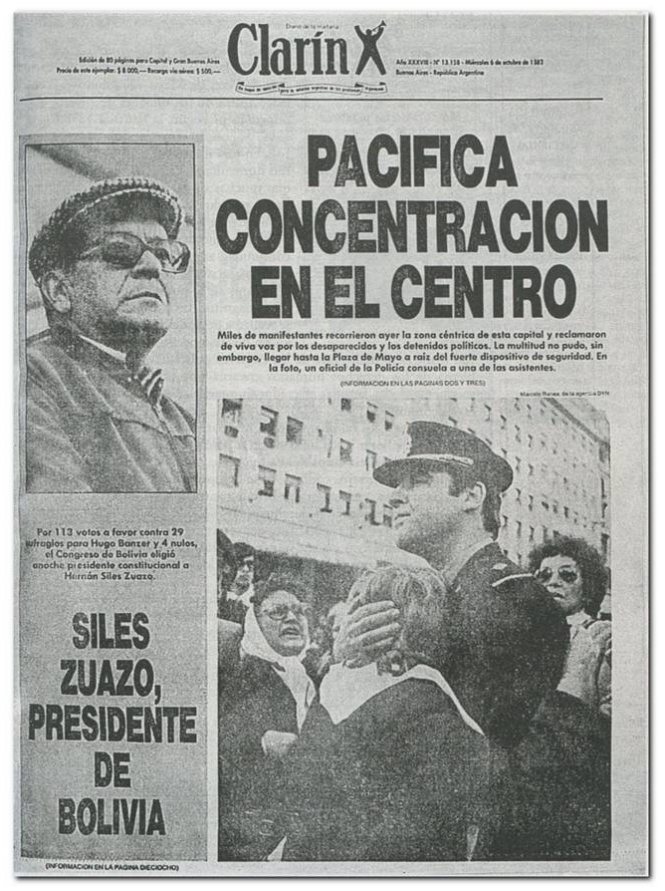

F5. Portada del diario Clarín, 6 / 10 / 1982.

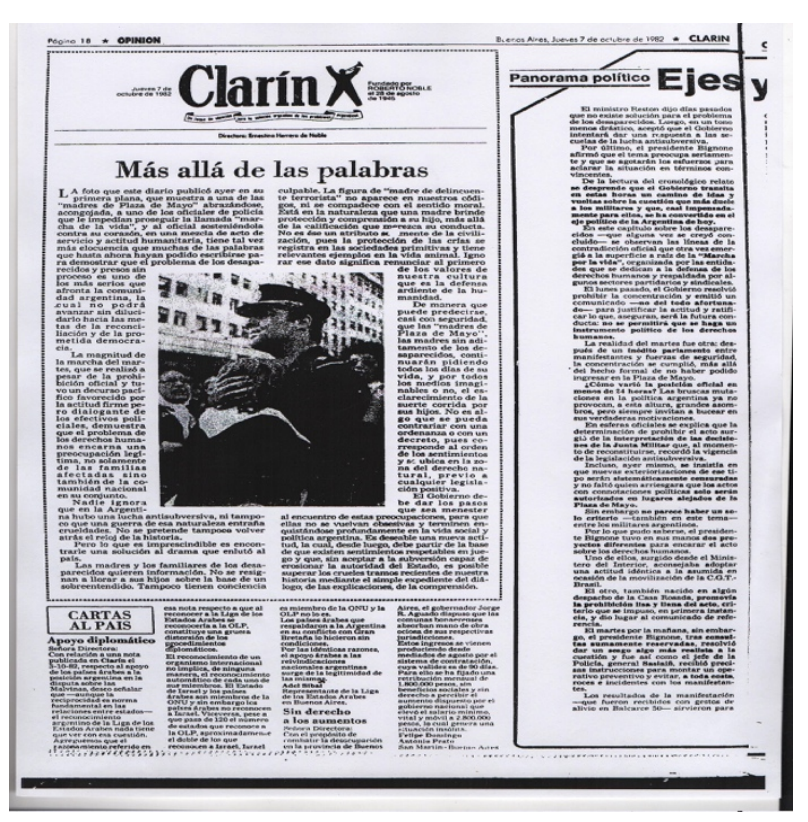

F6. Clarín, 7 / 10 / 1982, p. 18, editorial.

Era la primera vez que el diario publicaba una foto de una madre de un detenidodesaparecido a ese tamaño. En la nota en el interior del diario, se señalaba: "Una de las numerosas discusiones finalizó cuando una madre visiblemente emocionada se abrazó llorando a un policía, quien la apretó contra su pecho, igualmente sensibilizado” (Pacífica concentración en el centro, 1982, p. 48).

Al día siguiente, el 7 de octubre de 1982, en un segundo hecho inédito para el diario, Clarín volvió a publicar la foto. esta vez dentro de su columna editorial. Bajo el título "Más allá de las palabras” señala:

La foto que este diario publicó ayer en su primera plana, que muestra a una de las "Madres de Plaza de Mayo" abrazándose acongojada, a uno de los oficiales de policía que le impedían proseguir la llamada "marcha por la vida", y al oficial sosteniéndola contra su corazón, en una mezcla de acto de servicio y actitud humanitaria, tiene tal vez más elocuencia que muchas de las palabras que hasta ahora hayan podido escribirse para demostrar que el problema de los desaparecidos y presos sin proceso es uno de los más serios que afronta la comunidad argentina, la cual no podrá avanzar sin dilucidarlo hacia las metas de la reconciliación y de la prometida democracia. (Más allá de las palabras, editorial, 1982, p. 18)

Por su parte, el diario La Nación publicó el 7 de octubre tres fotos de las tomadas por Ranea bajo el título "Singular secuencia fotográfica”, pero falseó el orden 
cronológico en el que fueron tomadas. En un recuadro especial publicó los fotogramas 30, 31 y 29, en ese orden. Colocadas de esa manera, las fotos mostraban a Susana de Leguía llorando (fotograma 30), luego cómo ella comienza a irse (fotograma 31) y por último la escena del falso abrazo como si el oficial de policía la hubiese consolado (fotograma 29). Alterar el orden de la secuencia le daba aún más veracidad a aquello que no había sucedido.

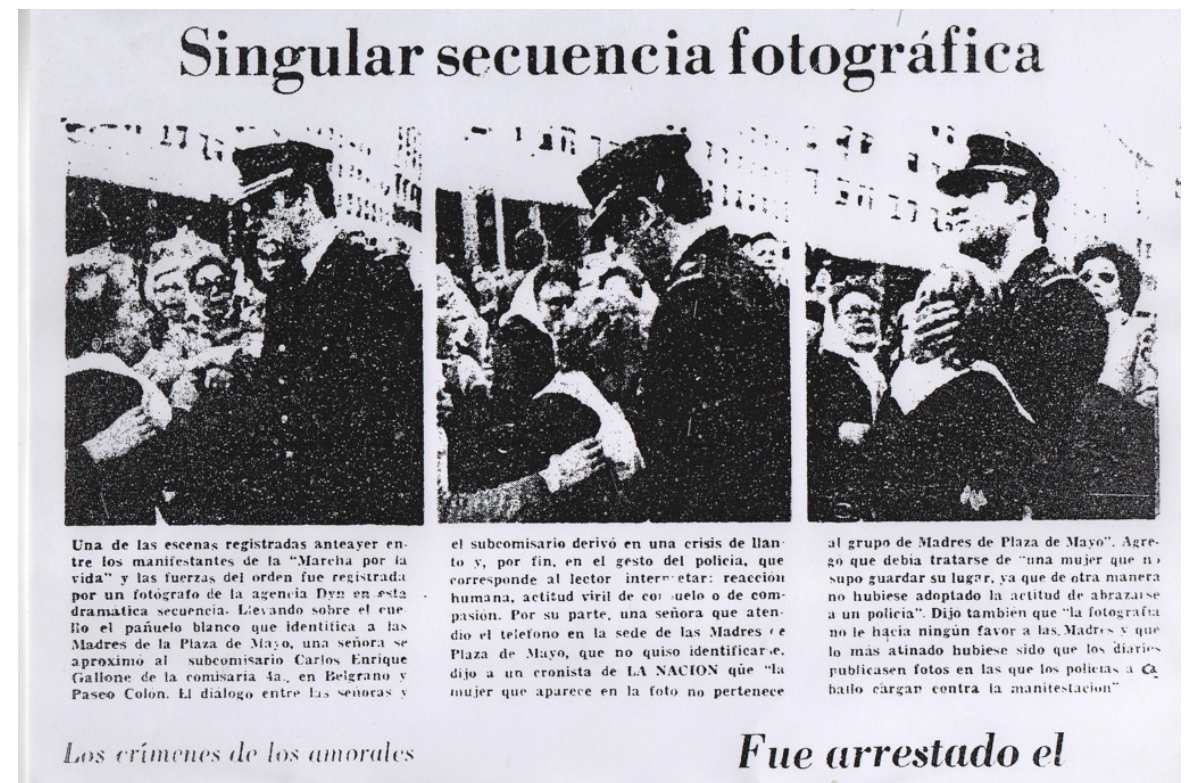

F7. Secuencia publicada en el diario La Nación el 7 de octubre de 1982 de los fotogramas 30, 31 y 29 alterando su orden original.

El diario El País de España la publicó como única foto en su portada el día 8 de octubre de 1982. Con un largo epígrafe encabezado por la frase "Algo más que una manifestación en Buenos Aires", se lee: "Un oficial de policía, encargado de reprimir a las Madres de Plaza de Mayo -que reclaman desde hace años la aparición de sus seres queridos-, consuela emocionado a una de las 10.000 personas que participaron el martes por la tarde en la Marcha por la Vida" (portada, la cursiva es nuestra) y la revista Siete Días (que en ese momento tenía fuertes vínculos con la Marina) publicó la foto a doble página con el título "Ella es madre, él es hijo", junto con un texto que decía:

El gesto espontáneo posterga el antagonismo para siempre (...). Es la imagen de un país que, a pesar de todo, ansía reencontrarse. Porque debajo del dolor de una madre que no sabe dónde está su hijo y debajo del uniforme azul de un policía hay dos seres humanos. (...) Nadie los obligó a abrazarse (...). Dos posiciones hasta hoy irreconciliables fundidas en una imagen que es todo un símbolo. 
Singularmente, en el costado izquierdo en la revista Siete Días aparece otra foto, que analizaremos más adelante.
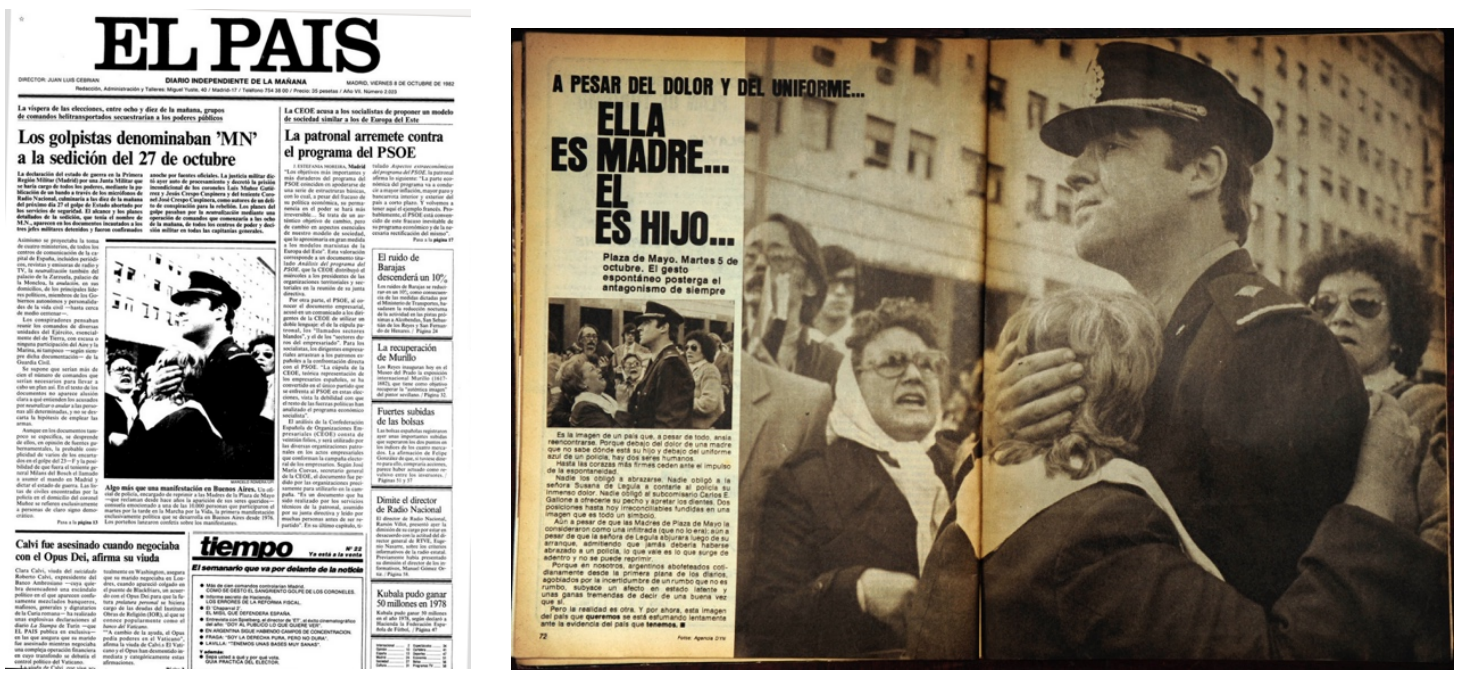

F8. Diario El País (España) del 8 de octubre de 1982 y revista Siete Días, 13 de octubre de 1982.

El único medio que puso en duda lo que la foto mostraba fue el diario La Voz. ${ }^{17}$ Lo hizo en una nota titulada: "Después del abrazo del policía y la madre. El Pueblo se pregunta si algo cambió en el país” (1982, p. 7). Allí, el diario entrevistaba a Hebe de Bonafini, presidenta de Madres de Plaza de Mayo en ese entonces, a Pérez Esquivel, premio Nobel de la Paz, y al propio Ranea, preguntándoles por el sentido de la imagen. ${ }^{18}$

La foto obtuvo el premio Rey de España a la mejor fotografía periodística del año 1983, otorgado por el Instituto de Cooperación Iberoamericana y la Agencia EFE, premio considerado como el más importante del fotoperiodismo de habla hispana. Fue la primera vez que una fotografía argentina ganó ese premio, lo que significó un gran éxito para el fotógrafo y un logro para una agencia que se había creado ocho meses antes del momento en que se tomó la imagen. Sin embargo, el propio Ranea señaló en el año 2013:

Sería más real, más acorde a la situación que se vivía ese día y en ese momento la 25 y no la 29. En la 25 Gallone está discutiendo con Nora de Cortiñas y en la 29 está abrazando a Susana de Leguía. Coincidía más con la situación en general la que está discutiendo con Nora, pero obviamente tenía mucho más punch la otra.

\footnotetext{
17. El diario $L a$ Voz se publicó entre 1982 y 1985. Para una historia del diario La Voz, ver Mancuso (2015).

18. Los testimonios están citados en Gamarnik (2020).
} 
En la cuestión de edición tiene mucho que ver el punch. (Testimonio en El Campo Cine, 2013)

Lo que Ranea denomina punch tiene que ver con los criterios de selección y edición en el fotoperiodismo que hacen que en ocasiones se priorice la espectacularidad, el impacto visual y la rareza por encima de una imagen que representaría mejor lo acontecido. En este caso, se enfrentaban como opciones una foto efectiva y sorprendente que no reflejaba la verdad de lo sucedido frente a otras fotografías que representaban más acabadamente los hechos ocurridos ese día y en ese momento. Pero, sobre todo, se trataba de una falacia visual a través de la cual se intentó instalar la idea de una posible reconciliación entre las Madres de Plaza de Mayo y las Fuerzas Armadas.

\section{La imagen de la reconciliación}

La foto de ese falso abrazo le dio fuerza, verosimilitud e impacto visual a la idea de reconciliación que algunos sectores de las fuerzas armadas, junto con algunos actores políticos, mediáticos y de la Iglesia católica, comenzaron a mencionar desde fines de 1981. La foto era un apoyo visual que servía para sostener y dar visos de realidad a esa noción de "cierre" del pasado que se vinculaba con la política de autoamnistía que la dictadura militar había puesto en marcha e intentaba implementar.

El andamiaje mediático que sostuvo y rodeó a la fotografía logró que un acontecimiento protagonizado por miles de manifestantes en contra de la impunidad, y que había sido reprimido, quedase reducido a una falacia visual que mostraba, indicaba y simbolizaba lo contrario. Por otra parte, a las distintas estrategias que había ensayado la dictadura para neutralizar, ocultar, desprestigiar y eliminar a las Madres se le sumó ahora la tergiversación de su postura histórica. Ellas jamás aceptarían ninguna reconciliación posible con los asesinos de sus hijos. ${ }^{19}$

\footnotetext{
19. Nora Cortiñas señala: "Ninguna madre en ningún momento ha pensado en la reconciliación con los genocidas. A veces las madres podemos estar en acuerdo o desacuerdo en algunas cosas en este caminar, pero en la reconciliación estamos todas de acuerdo en que no. Tendrían que emerger del fondo del mar, del fondo del río, de las tumbas anónimas, tendrían que emerger mis hijos, los hijos, las hijas y ser ellos los que dieran el perdón. Nosotras de ninguna manera. Ahí sí que se cometería un gran error. Pensar que las madres vamos a perdonar por lo que le hicieron a
} 
A pesar de los intentos de ocultarlas e invisibilizarlas, de la represión directa que incluyó violencia y amedrentamiento, campañas de desprestigio, el trato de locas y subversivas, las detenciones y en el caso más terrible los secuestros, torturas y asesinatos de sus compañeras, la dictadura no había podido frenar el reclamo y la movilización de las Madres de Plaza de Mayo. Por el contrario, hacia octubre de 1982 estaban acompañadas por sectores cada vez más amplios del arco político y de la población en general. A su vez, sus reclamos tenían legitimidad y visibilidad internacional.

Un sector de las Fuerzas Armadas, con el apoyo y en consonancia con lo que sostenían algunos medios de comunicación, vio en esta fotografía una posibilidad de cambio de imagen. A raíz de la repercusión de la fotografía, el Ministerio del Interior le envió felicitaciones al subcomisario Gallone por su "gesto humanitario” y el entonces comandante de la Armada, Rubén Franco, destacó la actitud del policía como un "gesto muy humano", señalando que a partir de ese momento existía "una nueva imagen de la Argentina": "con estas actitudes se ha comenzado a vivir el tiempo del entendimiento" (Después del abrazo del policía y la madre. El Pueblo se pregunta si algo cambió en el país, 1982, p. 7).

La importancia que un sector de las FF.AA. vinculado a la Secretaría de Información Pública (SIP), un organismo que dependía directamente del Poder Ejecutivo y bajo cuya órbita figuraba la agencia oficial de noticias Télam, le concedió a esta fotografía está demostrada en un hecho que adquirió mayor visibilidad en octubre de 2020. ${ }^{20}$

El 5 de octubre de 2020, otro reportero que estuvo en el lugar de los hechos escribió en su Facebook personal:

Soy Jorge Sánchez, reportero gráfico Nro 910, soy el autor de esta imagen. Hoy 510-2020 se cumplen 38 años de su captura, de la otra cara de la historia de la marcha de las Madres de Plaza de Mayo en 1982, en la que los protagonistas son la

\footnotetext{
nuestros hijos, a nuestras hijas. Eso no se va a dar nunca" (Testimonio en El Campo Cine, 2013). 20. La Secretaría de Información Pública tenía a su cargo la coordinación, la administración y la dirección de los principales medios de comunicación en aquel entonces: el Instituto de Cinematografía, la Dirección General de Radio y Televisión, la Agencia de Noticias -Télam-, el Ente de Calificación Cinematográfica y el Comité Federal de Radiodifusión -Comfer-. La SIP contaba con una Subsecretaría de Planeamiento y una Dirección General de Inteligencia, cuyas funciones eran controlar "el contenido de los mensajes que se transmiten o imprimen, para desvirtuar los negativos o incrementar los positivos". A finales de 1978, la SIP pasó a estar bajo control del Ejército. Para más información, ver Risler (2019) y Rodríguez (2015).
} 
madre Susana Leguía y el oficial Carlos Enrique Gallone, testigo de este momento fue Nora Morales de Cortiñas. Esta imagen la comparto hoy, después que fue censurada en aquel mismo día por el presidente de la agencia Télam, el coronel De Piano, cuando detrás de su escritorio sin mediar diálogo se escuchó con voz de mando 'esto de acá no tiene que salir publicado por su bien y retírese'. En la mañana siguiente se reflejaba en todas las portadas de los diarios argentinos la otra imagen que mostraba otra realidad de aquel momento histórico de aquella marcha y caminaba a un premio internacional. Les cuento que dos días después en la mañana del 8-10-1982 me cruzaba un vehículo en la intersección de la calle Ceballos y General Paz para trasladarme a un interrogatorio en un centro clandestino de detención con maltratos verbales y físicos para devolverme después de unas horas en la calle Nogoyá y Gral. Paz”.

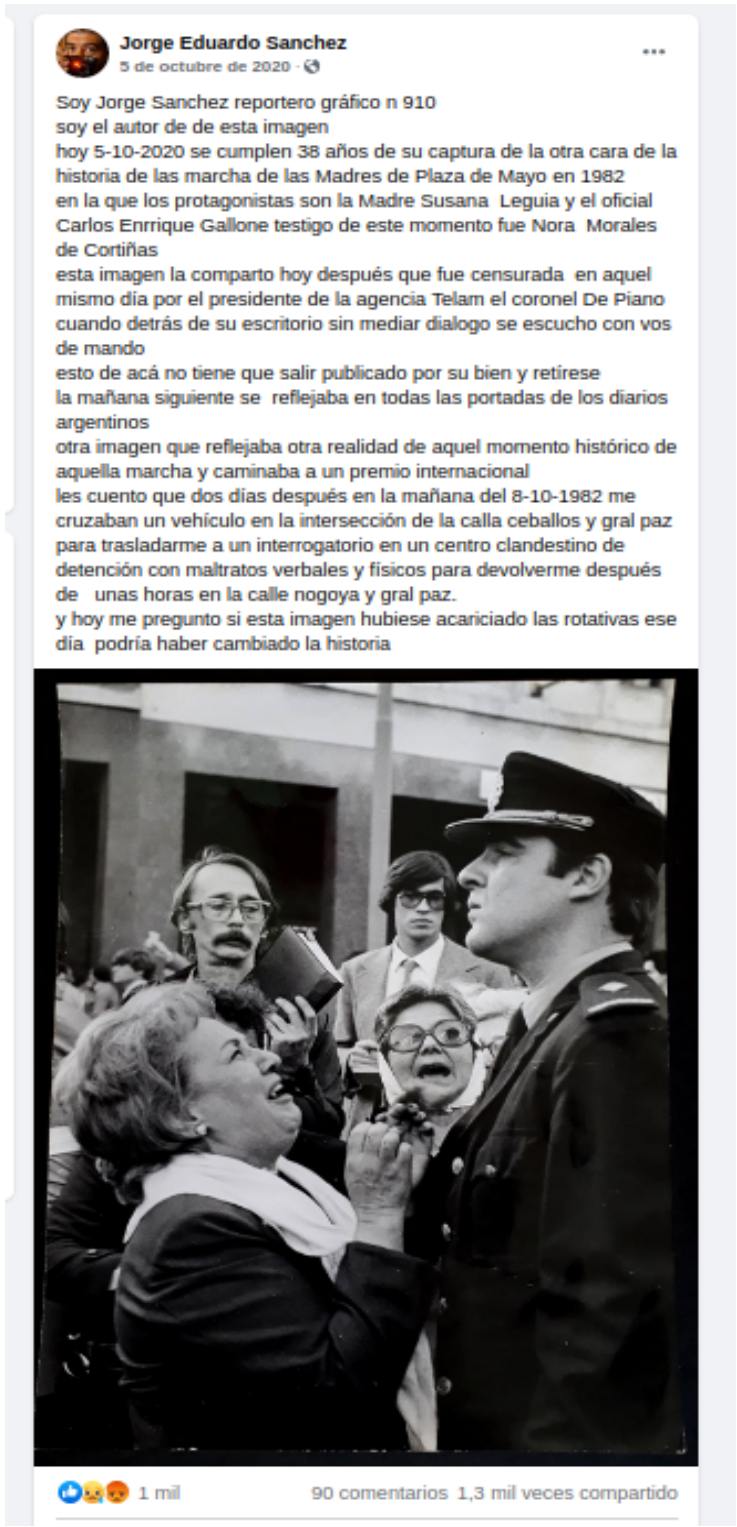

F9. Posteo del fotógrafo Jorge Sánchez, realizado el 5 / 10 / 2020 en su facebook personal. 
El testimonio de J. Sánchez viene a corroborar la importancia que tuvo la fotografía de Ranea y la operación política llevada a cabo para imponerla como relato privilegiado de los hechos. El recorrido de la foto de Sánchez, fotógrafo de la agencia oficial Télam en ese entonces, fue el inverso al de la foto de Ranea. Intentó ser ocultada, el fotógrafo fue secuestrado por unas horas y amedrentado para que no la mostrase. La foto fue misteriosamente descolgada cuando se expuso públicamente por primera y única vez en una muestra organizada por el Grupo de Reporteros Gráficos en noviembre de 1982. Como contó Sánchez, una vez en la agencia, y con el material revelado, fue citado por el coronel Rafael De Piano, director interventor de la agencia Télam y, con su foto sobre el escritorio, fue amenazado. ${ }^{21}$ De todas maneras, Sánchez realizó una copia a escondidas de su foto, la guardó en la agencia y un domingo, día de poco movimiento en Télam, se la llevó. ${ }^{22}$ Cuando, a fines de 1982, el Grupo de Reporteros Gráficos (GRG) comenzó a organizar lo que sería la segunda muestra de Periodismo Gráfico Argentino, Sánchez decidió enviar su foto para la exposición. Al diseñar la exposición, los fotógrafos decidieron colgarlas una al lado de la otra. La muestra contaba en esta oportunidad con el auspicio de la OEA (Organización de Estados Americanos), que, además, prestaba el lugar para su realización, un edificio en Avenida de Mayo $\mathrm{n}^{\mathrm{0}} 760$, perteneciente al Ministerio del Interior. Antes de ser inaugurada la exposición, la foto de Sánchez desapareció misteriosamente. Nadie supo lo que sucedió. Los organizadores ofrecieron al autor hacer una nueva copia y volverla a colgar, pero él prefirió no hacerlo.

La historia de la foto de Sánchez, las amenazas que recibió, lo que le sucedió después, la desaparición de la imagen en la exposición, sumada a la publicación en la prensa afín al régimen de modo descontextualizado y desvirtuado de la foto

\footnotetext{
21. En una entrevista que le había realizado previamente Jorge Sánchez, relató que De Piano le dijo: "Que esta foto no salga de acá porque si lo hace, usted y su familia van a tener problemas" (comunicación personal, 15 de septiembre de 2011). En otro intercambio de mensajes en noviembre de 2019, señaló que después de ese amedrentamiento fue levantado por un auto cuando salía de su casa para el trabajo y lo tuvieron retenido en un lugar desconocido: "Siempre la pregunta era por qué había ido a esa manifestación, por qué sacaba esas fotos, que eso no tenía que salir en ningún lado... Mientras tanto en la agencia decían que yo estaba de viaje”.

22. "Un día llego y en la ampliadora estaba mi foto puesta. Entonces yo rápido agarré un papel, lo puse así nomás, por eso está mal copiada, porque no tenía tiempo de detalle. La revelé, ni siquiera la sequé, la dejé mojada así y la metí en el armario que tenía. (...) Un domingo que había fútbol me la pude llevar" (J. Sánchez, comunicación personal, 15 de septiembre de 2011).
} 
de Ranea son la prueba palmaria de que se realizó una operación para sostener como única versión de lo sucedido la foto del falso abrazo.

La imagen que aquí estudiamos fue utilizada de manera diferenciada por muchos actores diferentes. Las FF.AA., los diarios, la Iglesia, la agencia DYN, el fotógrafo y el policía involucrado. ${ }^{23}$ Cada uno según sus propios fines e intencionalidades. En el año 2008, cuando Gallone estaba siendo juzgado por los delitos de lesa humanidad que había cometido, intentó utilizar la fotografía para mostrarse como un policía humanitario. Gallone declaró que ese día le tocó "cuidar a las Madres de Plaza de Mayo, a las viejitas, abuelitas que los jueves daban vueltas” y "trataban de llegar a Casa de Gobierno". Al volver "una ancianita me dijo 'gracias, hijo' y se puso a llorar en mi pecho. Días después, la foto recorrió el mundo” (Martínez, 30 de abril del 2008, Página 12, p. 1).

\section{Conclusiones. Límites y paradojas de una fotografía de prensa}

La fotografía que aquí analizamos permite poner en jaque la vinculación lineal que se suele establecer entre fotografías de prensa y aquello que denominamos “realidad". Demuestra una vez más que la fotografía es un objeto potente y ambiguo que se resiste a significados unívocos. Es un ejemplo al mismo tiempo de sus límites y de su paradojal influencia. En este caso, la fortaleza que la fotografía tiene para ser considerada "prueba" de un acontecimiento se volvió contra sí misma. El hecho de que la imagen haya sido obtenida por un fotoperiodista que trabajaba en una agencia reconocida, cumpliendo todas las normas exigidas por la profesión de no alterar la imagen ni el hecho fotografiado, que haya sido seleccionada por un editor de prestigio, distribuida y publicada en medios nacionales e internacionales, acompañada por títulos, epígrafes,

\footnotetext{
23. El oficial Carlos Enrique Gallone se encuentra hoy detenido por haber participado en delitos de lesa humanidad. Según señala el CELS (Centro de Estudios Legales y Sociales), Gallone fue uno de los principales responsables del grupo de tareas de la Superintendencia de Seguridad Federal Coordinación Federal. La justicia argentina probó que cometió privaciones ilegales de la libertad, aplicó tormentos y cometió delitos de violencia sexual, que dirigió especialmente hacia mujeres secuestradas. Entre las víctimas de Gallone, estuvieron Patrick Rice, Fátima Edelmira Cabrera y María Alonso. Gallone participó también de la llamada "Masacre de Fátima”, en la que aparecieron treinta cadáveres de detenidos-desaparecidos dinamitados en la localidad de Pilar, provincia de Buenos Aires. En aquel momento, Gallone pertenecía a la Seccional 4ta de la Policía Federal y actuaba bajo las órdenes del entonces ministro del Interior Albano Harguindeguy. Fuentes: CELS, 2019 y Soldado de Harguindeguy, 2009.
} 
comentarios y relatos y que, por último, haya obtenido el premio a la mejor fotografía periodística en medios de habla hispana logró producir su efecto de realidad.

Las fotografías periodísticas están investidas de un halo de autenticidad. Como señaló Barthes (1986): "Si bien es cierto que la imagen no es lo real, es por lo menos su analogon perfecto, y es precisamente esa perfección analógica lo que, para el sentido común, define la fotografía”. El aspecto técnico de la fotografía refuerza esta idea. El fotógrafo "estuvo allí” donde sucedió el hecho y el acontecimiento fotografiado quedó en el objetivo. "Eso ha sido", dice Barthes. Sin embargo, lo que vemos en la fotografía que aquí analizamos "no ha sido". La inautenticidad de la imagen está en la propia limitación de la fotografía para mostrar un suceso y en la cadena de edición y usos posteriores que se le dio a la misma. Esta fotografía muestra la debilidad y a la vez la potencialidad que tiene la fotografía de prensa. Al ser una fracción de segundo recortada del tiempo, al imponer una discontinuidad, la imagen nos introduce tanto en la problemática de la fugacidad como de la permanencia. "Ni la madre ni el policía querían abrazarse, no hay expresión de cariño, ni de afecto ni de contención en sus intenciones. Sin embargo, ese instante congelado en el tiempo, multiplicado y repetido con la fuerza de la reproducción, quedó para la historia. La fotografía no informa del acontecimiento en sí sino del instante en que este fue congelado" (Gamarnik, 2020).

La imagen aportaba, sin embargo, la "prueba" necesaria de lo que allí se veía. Para acentuar la credibilidad, la fotografía se mostró aislada y descontextualizada de la secuencia que le dio origen, se alteró el orden en el que fue obtenida, se la acompañó de títulos, editoriales y epígrafes que la explicaban en un solo sentido, se ocultaron otras fotografías que alteraban su interpretación y se amenazó y silenció al fotógrafo que podía sostener lo contrario.

Roland Barthes (1986) señala que toda fotografía es vista como una emanación de lo real en el pasado y construye una nueva existencia a partir del instante en que es capturada. Es por eso que habla de la "irrealidad real de la fotografía". La imagen es capturada, pero a partir de ese instante se independiza, construye una nueva existencia. Por eso, puede decirse que la fotografía posee una autonomía estructural. Es un objeto histórico que produce sentidos dentro de un universo 
social particular. La fotografía se presenta como materia objetivada y abre la posibilidad a nuevas interpretaciones y usos. Una vez capturada, empieza su propio recorrido comunicativo. Se le escapa de las manos al fotógrafo, a la agencia, a los medios y a los protagonistas de los hechos. Dicha autonomía relativa es uno de los aspectos de la fotografía más interesantes y problemáticos al mismo tiempo, ya que un fragmento de la realidad se convierte en forma, objeto y representación aislada de la situación que le dio origen. Persiste la huella de la realidad, pero se independiza de la misma. Al ser separada de su contexto, la imagen se presta a usos arbitrarios. Por eso, puede decirse que fotografiar es en esencia descontextualizar. Historizar una imagen es entonces necesariamente volver a ponerla en contexto, reponer lo ausente y recuperar las voces silenciadas. Como sostiene Judith Butler,

(...) si la fotografía no solo retrata sino que también construye sobre y aumenta el acontecimiento -si puede decirse que la fotografía reitera y continúa el acontecimiento-, entonces no difiere del acontecimiento estrictamente hablando, sino que se torna crucial para su producción, su legibilidad, su ilegibilidad y su estatus mismo como realidad. (Butler, 2010, p. 121)

Que la imagen se haya utilizado como símbolo de reconciliación entre las Fuerzas Armadas y los organismos de derechos humanos fue posible, en gran medida, por las estrategias de descontextualización, pero también de recontextualización en la que fue inmersa. Palabras e imagen se complementaron y reforzaron para decir lo que no había sucedido.

Las operaciones discursivas que se hicieron desde los medios -los títulos y textos que la acompañaron, las decisiones editoriales de publicarla alejada de la secuencia en la que estaba incluida, la censura de la foto de Sánchez, el hecho de no mostrar la verdadera naturaleza represiva que había tenido la marcha ese díahicieron posible que esta imagen se instalase como una visión realista de lo sucedido y que sea una de las fotos más reproducidas para hablar de la dictadura militar argentina.

En esta imagen se condensan todos los problemas alrededor del análisis de lo fotográfico. No nos muestra un hecho fantástico o imaginario, no está manipulada, el instante existió, el referente estuvo allí y el registro de la cámara lo demuestra. La imagen cumplió todas las reglas del registro periodístico, pero, 
sin embargo, el abrazo no fue tal. Necesitamos recurrir a otras imágenes, a la historia oral y al contraste de testimonios para reconstruir lo sucedido. Analizar la cadena de edición y los diferentes usos mediáticos que se le dieron, compararla con otras fotografías, ponerla en serie, reconstruir la historia. Vista de esta manera, la fotografía que aquí analizamos no tiene una significación en sí misma. El sentido de la imagen es exterior a ella.

\section{Referencias bibliográficas}

A las 17, en Plaza de Mayo, se hará la "Marcha por la Vida". (5 de octubre de 1982). La Voz.

Algo más que una manifestación en Buenos Aires. (8 de octubre de 1982). El País.

Barthes, R. (1986). El mensaje fotográfico, La retórica de la imagen. En Lo obvio y lo obtuso. Imágenes, gestos, voces. Barcelona: Paidós.

Barthes, R. (2006). La cámara lúcida. Nota sobre la fotografía. Buenos Aires: Paidós.

Berger, J. (2017). Otra manera de contar. En Para entender la fotografía. Barcelona: Gustavo Gili.

Bousquet, J-P. (1983). Las locas de la Plaza de Mayo. Buenos Aires: El Cid.

Butler, J. (2010). Marcos de guerra. Las vidas lloradas. Buenos Aires: Paidós.

Calveiro, P. (1998). Poder y desaparición. Buenos Aires: Colihue.

CELS (2019). Superintendencia de Seguridad Federal: 43 años después de los hechos, el juicio terminó con condenas. Recuperado de https://www.cels.org.ar/web/2019/12/superintendencia-de-seguridadfederal-43-anos-despues-de-los-hechos-el-juicio-termino-con-condenas/

Después del abrazo del policía y la madre. El Pueblo se pregunta si algo cambió en el país. (8 de octubre de 1982). La Voz, p. 7.

Dubois, P. (2008). El acto fotográfico y otros ensayos, Capítulo 1. De la verosimilitud al índex. Pequeña retrospectiva histórica sobre la cuestión del realismo en fotografía. Buenos Aires: La Marca.

El abrazo partido. (11 de septiembre de 2011). La Jornada. Recuperado de http://www.diariojornada.com.ar/Noticia/Default.aspx?id=24537

El Campo Cine (2013). Fotos. Retrato de un país. Canal Encuentro. Recuperado de https://www.youtube.com/watch?v=VMiKoKATSFo\&feature=youtu.be

El Periodismo Gráfico Argentino, reseña (1984). Reportero Gráfico, (4), p. 28.

Ella es madre, él es hijo. (13 de octubre de 1982). Siete Días.

Filc, J. (1997). Entre el parentesco y la política. Familia y dictadura, 1976-1983. Buenos Aires: Biblos. 
Franco, M. (2018). El final del silencio. Dictadura, sociedad y derechos humanos en la transición (Argentina, 1979-1983). Buenos Aires: Fondo de Cultura Económica.

Gamarnik, C. (2010). La construcción de la imagen de las Madres de Plaza de Mayo a través de la fotografía de prensa. Revista Afuera. Estudios de Crítica Cultural. Artes Visuales, (9). Recuperado de http://www.revistaafuera.com/articulo.php?id=129

Gamarnik, C. (2020). Fotografía de prensa y dictadura en Argentina: la historia de un falso abrazo. En G. Aguila, S. Garaño \& P. Scatizza (Eds.), La represión como política de Estado. Estudios sobre la violencia estatal en el siglo $X X$ (pp. 169-194). Buenos Aires: Imago Mundi.

Gorini, U. (2006). La rebelión de las Madres. Historia de las Madres de Plaza de Mayo, Tomo I (1976-1983). Buenos Aires: Grupo Editorial Norma.

Joly, M. (2009). Introducción al análisis de la imagen. Buenos Aires: La Marca.

Mancuso, M. (2015). La Voz: el otro diario de los Montoneros. Buenos Aires: Punto de Encuentro.

Martínez, D. (30 de abril de 2008). Gallone le echa la culpa a la foto. Empezó el juicio contra tres policías retirados por la masacre de Fátima. Página 12, p. 1.

Más allá de las palabras, editorial. (7 de octubre de 1982). Clarín, p. 18

Pacífica concentración en el centro. (6 de octubre de 1982). Clarín, p. 48.

Pacífica marcha por la vida pese a la prohibición. (6 de octubre de 1982). Crónica.

Risler, J. (2019). La acción psicológica: dictadura, inteligencia y gobierno de las emociones (1955-1981). Buenos Aires: Tinta Limón.

Rodríguez, L. (2015). Cultura y dictadura en Argentina (1976-1983): estado, funcionarios y políticas. Anuario Colombiano de Historia Social y de la Cultura, $\quad 42 \quad$ (2), 299-325. Recuperado de http://www.memoria.fahce.unlp.edu.ar/art_revistas/pr.9184/pr.9184.p df

Sánchez, M. V. (2009). Abrazar una imagen. Algunas reflexiones acerca de las relaciones entre imagen y memoria desde una fotografía. [CD-ROM del Primer Congreso de Sociólogos de la Provincia de Buenos Aires, La Plata].

Silveyra, S. (2008), Un tiempo después, Telefé. Recuperado de http://www.youtube.com/watch?v=JIW5IuOrOZQ\&feature=related

Singular secuencia fotográfica. (7 de octubre de 1982). La Nación.

Soldado de Harguindeguy. (8 de julio de 2009). Página 12. Recuperado de http://www.pagina12.com.ar/diario/elpais/subnotas/127908-410322009-07-08.html 